УДК 614.3

О РАЗВИТИИ СИСТЕМЫ РИСК-ОРИЕНТИРОВАННОГО НАДЗОРА

В ОБЛАСТИ ОБЕСПЕЧЕНИЯ САНИТАРНО-ЭПИДЕМИОЛОГИЧЕСКОГО БЛАГОПОЛУЧИЯ НАСЕЛЕНИЯ И ЗАЩИТЫ ПРАВ ПОТРЕБИТЕЛЕЙ

\author{
А.Ю. Попова ${ }^{1}$, Н.В. Зайцева ${ }^{2}$, И.В. Май ${ }^{2}$, Д.А. Кирьянов 2 \\ ${ }^{1}$ Федеральная служба по надзору в сфере защиты прав потребителей и благополучия человека, \\ Россия, 127994, г. Москва, Вадковский переулок, 18, строение 5 и 7 \\ ${ }^{2}$ ФБУН «Федеральный научный центр медико-профилактических технологий управления рисками \\ здоровью населения», Россия, 614045, г. Пермь, ул. Монастырская, 82
}

С иелью реализации законодательных требований по переходу на новую риск-ориентированную модель осуществления государственного контроля (надзора) Федеральной службой в сфере защиты прав потребителей и благополучия человека разработаны методические подходы по классификации хозяйствующих субъектов и видов деятельности по потенциальному риску причинения вреда здоровью. При оценке риска учитывается частота нарушения санитарного законодательства, тяжесть последствий этих нарушений для здоровья и масштаб негативных последствий, который оиенивается по численности населения под воздействием хозяйствующего субъекта. Разработаны алгоритмы и методы расчета численности населения под воздействием: работников, потребителей, в том числе потребителей продовольственных товаров, непродовольственных товаров, услуг; жителей населенных пунктов, находящихся под негативным влиянием загрязнения атмосферного воздуха, водных объектов, почв. Сформированы региональные и федеральный реестры объектов, подлежащих санитарно-эпидемиологическому надзору.

Апробация в регионах страны риск-ориентированных подходов позволила при формировании планов проверок на 2016 г. исключить объекты низкого риска причинения вреда, за счет чего в целом по стране плановые проверки сократились более чем на $20 \%$.

Определены основные направления дальнейшего совершенствования риск-ориентированной модели санитарноэпидемиологического надзора: ее расширение на системы технического регулирования и защиты прав потребителей; научное обоснование объемов, содержания и лабораторного сопровождения плановых проверок объектов, относящихся к разным классам по риску причинения вреда здоровью населения; совершенствование порядка и методов оценки результативности и эффективности риск-ориентированной надзорной деятельности; создание эффективной системы риск-коммуникаџий между органами санитарно-эпидемиологического надзора, хозяйствующими субъектами, общественными организачиями и объединениями и гражданским обществом.

Ключевые слова: риск-ориентированный санитарно-эпидемиологический надзор, население под воздействием.

Тринадцатого июля 2015 г. Президентом Российской Федерации подписан Федеральный закон № 246-Ф3, который вносит существенные дополнения и изменения в Федеральный закон № 294-Ф3 от 26 декабря 2008 г. «О защите прав юридических лиц и индивидуальных предпринимателей при осуществлении государственного контроля (надзора) и муниципального контроля». Кроме вывода из-под пла- новых проверок (за определенным исключением) субъектов малого предпринимательства основные новшества, вводимые данным Законом, касаются перехода на новую модель осуществления государственного контроля (надзора), основывающуюся на применении рискориентированного подхода. В соответствии с положениями закона риск-ориентированный подход при проведении государственного кон-

(ㄷ Попова А.Ю., Зайцева Н.В., Май И.В., Кирьянов Д.А., 2015

Попова Анна Юрьевна - доктор медицинских наук, руководитель (e-mail: depart@gsen.ru; тел.: 8 (499) 458-95-63).

Зайцева Нина Владимировна - академик РАН, доктор медицинских наук, профессор, директор (e-mail: znv@fcrisk.ru; тел.: 8 (342) 237-25-34).

Май Ирина Владиславовна - доктор биологических наук, профессор, заместитель директора по научной работе (e-mail: may@fcrisk.ru; тел.: 8 (342) -236-32-64).

Кирьянов Дмитрий Александрович - кандидат технических наук, заведующий отделом математического моделирования систем и процессов (e-mail: kda@fcrisk.ru; тел.: 8 (342) 237-18-04). 
троля (надзора) будет применяться при планировании надзорных проверок, начиная с 2018 г.

Роспотребнадзор является одним из первых федеральных органов исполнительной власти, который разработал и апробировал научно-методические подходы к риск-ориентированной модели контрольно-надзорной деятельности и выполнил целых ряд организационных шагов для ее внедрения [1].

Утвержденные приказом руководителя службы № 1302 от 26.12.2014 г. методические рекомендации по классификации объектов санитарно-эпидемиологического надзора по потенциальному риску причинения вреда здоровью [5] предусматривали выделение четырех классов хозяйствующих субъектов - чрезвычайно высокого, высокого, среднего и низкого риска.

Установление потенциального риска причинения вреда базируется на принципах, используемых в мировой практике многими государственными надзорными органами [2, 8-11]:

- риск причинения вреда здоровью возникает в условиях нарушения объектом надзора требований, установленных законодательством в сфере санитарно-эпидемиологического благополучия населения и защиты прав потребителей;

- нарушение законодательства в сфере санитарно-эпидемиологического благополучия и защиты прав потребителей определяет вероятность ухудшения параметров среды обитания человека, безопасности товаров и услуг и связанную с этим вероятность нарушения здоровья населения, работающих, потребителей, находящихся под воздействием объекта надзора;

- оценка потенциального риска причинения вреда здоровью выполняется в отношении определенного вида деятельности юридического лица или индивидуального предпринимателя, при этом класс опасности хозяйствующего субъекта устанавливается по наиболее опасному виду деятельности;

- порядок и критерии отнесения объектов к тому или иному классу опасности по риску причинения вреда здоровью являются единообразными для всех юридических лиц и индивидуальных предпринимателей независимо от вида деятельности и форм собственности;

- отнесение организации к конкретному классу опасности является основанием для установления периодичности плановых проверок; объемов и содержания надзорных мероприятий. Частота плановых проверок для объектов, не формирующих чрезвычайно высокого и вы- сокого риска, может варьироваться даже для объектов, относимых к одному классу;

- при планировании надзорных мероприятий внутри класса определяются приоритеты с учетом результатов предыдущих контрольнонадзорных мероприятий в отношении конкретной организации, включая результаты лабораторных исследований. Таким образом «степень законопослушания» хозяйствующего субъекта может влиять на частоту плановых контрольнонадзорных мероприятий.

Класс опасности по потенциальному риску причинения вреда здоровью рассматривается как характеристика объектов надзора, устанавливаемая с учетом:

- частоты нарушения санитарного законодательства при осуществлении определенного вида деятельности (определяется как 95\%-ный персентиль частоты нарушений на 1 проверку по данным контрольно-надзорной деятельности за три года по всем субъектам Российской Федерации);

- тяжести последствий для здоровья, которые могут наступить при нарушении этих требований;

- масштабности негативных последствий, которые оцениваются по численности населения, находящегося под воздействием того или иного вида деятельности хозяйствующего субъекта (1).

$$
R_{j}=p_{k j} u_{i j} N_{k j},
$$

где $R_{j}$ - риск причинения вреда здоровью от $j$-го вида деятельности, $p_{k j}$ - вероятность нарушения санитарного законодательства по $k$-й статье $j$-го вида деятельности санитарного законодательства; $u_{i}$ - вред, обусловленный $i$-м нарушением здоровья, связанный с нарушением законодательства; $N_{k j}$ - численность населения, находящегося под воздействием при нарушении санитарного законодательства по $k$-й статье $j$-го вида деятельности. Риск для юридического лица (ЮЛ) или индивидуального предпринимателя (ИП) по $j$-му виду деятельности характеризуется суммой риска по объектам надзора данного хозяйствующего субъекта.

Первые две составляющие ( $p$ и $u$ ) определяются по данным государственной статистики и математического моделирования причинноследственных связей в системе «нарушения законодательства - показатели состояния здоровья населения», характеризуют конкретный вид хо- 
зяйственной деятельности и являются общими для объектов данного вида деятельности.

Третья составляющая $(N)$ является уникальной для объекта, характеризует масштаб его влияния и вносит существенный вклад в уровень потенциального риска. К примеру, при одних и тех же нарушениях обязательных требований к микробному или химическому составу питьевой воды источник водоснабжения, запитывающий поселение с численностью 1 млн человек, формирует существенно больший популяционный риск, чем источник, запитывающий 10 тысяч человек.

С целью корректной оценки численности населения под воздействием были разработаны и апробированы методические рекомендации, в которых определены алгоритмы и методы расчета количества населения под воздействием:

- работников предприятий и организаций;

- потребителей, в том числе потребителей продуктов питания, непродовольственных товаров, услуг;

- жителей населенных пунктов, находящихся под воздействием загрязнения атмосферного воздуха, водных объектов, почв.

Сложность решения задачи определения населения под воздействием состояла в выборе показателей, которые с определенной степенью генерализации, без избыточной деталировки, но единообразно и обоснованно позволяли бы оценивать численность экспонированного населения.

Было предложено:

- рассчитывать численность работников, в том числе работающих во вредных и опасных условиях труда, по данным самих хозяйствующих субъектов или с учетом средних показателей по доле работников во вредных условиях труда;

- устанавливать численность потребителей услуг на основе данных, предоставляемых хозяйствующими субъектами о количестве мест, на которых предоставляется услуга;

- определять численность потребителей товаров (продовольственных и непродовольственных) по данным об объемах производимых или реализованных товаров, предоставляемых хозяйствующими субъектами, иными источниками данных или в соответствии с параметрами аналогичных объектов.

- рассчитывать численность населения, находящегося в зоне воздействия загрязнений атмосферного воздуха и загрязнения почв, исходя из размеров ориентировочной санитарнозащитной зоны в соответствии с главой VII СанПиН 2.2.1/2.1.1.1200-03, а также плотности населения пункта, в котором расположен объект надзора. При наличии результатов расчетов рассеивания вредных примесей от объекта, нарушившего санитарные требования к качеству атмосферного воздуха, численность населения под воздействием определяется как количество людей, проживающих на территории, описываемой внешней изолинией 1 ПДК (с учетом совокупности веществ).

При отсутствии результатов расчетов рассеивания определение численности населения, находящегося под вредным воздействием загрязнений атмосферного воздуха, производится по формуле (1):

$$
N=3 \pi r^{2} \rho 10^{-6}+N_{\mathrm{c} 33}=9,42 r^{2} \rho 10^{-6}+N_{\text {с } 33}
$$

где $\pi=3,14$;

$N$ - численность населения, находящегося под вредным воздействием загрязнения атмосферного воздуха, млн человек;

$r$ - размер нормативной санитарно-защитной зоны, м;

$$
\rho \text { - плотность населения, чел./км²; }
$$

$N_{\text {сзз }}$ - численность населения, проживающего в санитарно-защитной зоне, млн человек, $10^{-6}$ - коэффициент переведения м ${ }^{2}$ в км².

При этом не исключается использование более точных методов расчета, к примеру с применением расчетов рассеивания выбросов в атмосферный воздух, расчетов смешения-разбавления сточных вод и добегания загрязнения до створов водопользования и т.п. [3].

Важным элементом учета численности населения под воздействием объекта надзора для задач классификации по степени риска причинения вреда является учет меры контакта опасного фактора с человеком (время контакта, объем потребления в единицу времени). Предложен подход, формализованный в уравнениях 2 и 3 :

$$
M=N T,
$$

где $M$ - показатель, характеризующий среднегодовую численность и меру контакта населения при воздействии факторов потенциального риска причинения вреда здоровью человека объектами надзора, млн человек; $N$ - численность населения (работников, потребителей товаров и услуг, жителей), находящегося под воздействием факторов риска объектов надзора в сутки, млн человек; $T$ - безразмерный коэффициент, учитывающий среднегодовое время контакта или объем потребления. 
Общая формула для расчета коэффициента, учитывающего время контакта:

$$
T=\frac{t_{1}}{24} \cdot \frac{t_{2}}{365},
$$

где $t_{1}$ - время контакта человека (работника, потребителя услуги, жителя) с опасным фактором риска объекта надзора в течение суток, ч;

$t_{2}$ - количество дней в году вероятного контакта человека (работника, потребителя услуги, жителя) с опасным фактором риска объекта надзора, сут.

Численность населения, находящегося под вредным воздействием загрязнений водных объектов, определяется только для объектов надзора, имеющих источники сброса сточных, в том числе дренажных, вод в водные объекты, используемые для целей питьевого, хозяйственнобытового водоснабжения, а также для лечебных, оздоровительных и рекреационных целей.

Для субъектов хозяйственной деятельности (объектов надзора), имеющих сброс сточных вод и установленные нормативы допустимого сброса, численность населения, находящегося под вредным воздействием загрязнений водных объектов, определяется:

a) при наличии водозабора хозяйственнопитьевого назначения, расположенного ниже по течению от места сброса сточных вод, как суммарная численность населения, запитанного от этого водозабора. Учитывается численность населения всех мест водопользования до створа разбавления сточных вод на уровне ПДК. Время потенциального контакта - круглосуточно;

б) при отсутствии водозабора хозяйственно-питьевого назначения учитывается население, использующее водный объект для рекреационных целей. Численность населения определяется максимальной емкостью рекреационной зоны. Время потенциального контакта - продолжительность рекреационного сезона.

Коэффициент, учитывающий время экспозиции для объектов хозяйственной деятельности (объектов надзора), имеющих сброс сточных вод, определяется исходя из круглосуточного нахождения в течение года $\left(t_{1}=24, t_{2}=365\right)$ и равен $T=1$.

Численность населения, находящегося под вредным воздействием загрязнений почв, определяется только для объектов, имеющих места складирования отходов, и рассчитывается исходя из размеров С33 аналогично расчетам по атмосферному воздуху. Время потенциального контакта - круглосуточно.
Подготовлен справочный материал, облегчающий оценку численности населения под воздействием опасных факторов при ведении деятельности в области здравоохранения, образования, организации отдыха, развлечений, культуры и спорта, предоставления персональных услуг и т.п.

Важным этапом внедрения риск-ориентированнй модели явилось формирование региональных и федерального реестров юридических лиц и индивидуальных предпринимателей, чья деятельность подлежит санитарно-эпидемиологическом надзору и надзору в сфере защиты прав потребителей [4].

На настоящее время ${ }^{1}$ федеральный реестр содержит данные о более чем 694,4 тыс. юридических лиц и индивидуальных предпринимателей и 1,24 млн принадлежащих им объектов надзора, расположенных во всех 85 субъектах федерации. Реестр является «живым», требует постоянного ведения, корректировки, актуализации. При этом реестр является универсальной информационной базой для целого ряда аналитических обобщений и оценок.

Так, реализация принятых подходов к классификации объектов надзора на данных региональных реестров Иркутской области, Красноярского и Пермского краев показала, что классификация объектов надзора не на четыре класса, как было предложено на начальной стадии формирования модели, а на шесть классов делает систему дифференциации объектов по потенциальному риску причинения вреда здоровью и систему определения периодичности плановых проверок более гибкой (табл. 1) [6].

В полном соответствии с законодательными требованиями периодичность проведения плановых мероприятий государственного контроля (надзора) последовательно снижается от вышестоящей категории риска к нижестоящей категории.

Для организаций, которым присвоена категория чрезвычайно высокого риска, устанавливается режим постоянного государственного санитарно-эпидемиологического контроля (надзора), который заключается в возможности постоянного пребывания уполномоченных должностных лиц органов санитарного надзора на объектах организаций и проведения указанными лицами мероприятий по предупреждению, выявлению и пресечению нарушений обязательных требований к осуществлению деятельности на таких объектах.

\footnotetext{
${ }^{1}$ На 15 декабря 2015 г.
} 
Т а б ли ц а 1

Классификация объектов надзора степени потенциального риска причинения вреда здоровью

\begin{tabular}{|c|c|c|c|}
\hline Класс опасности & $\begin{array}{c}\text { Характеристика риска } \\
\text { причинения вреда здоровью }\end{array}$ & $\begin{array}{c}\text { Риск причинения } \\
\text { вреда здоровью }\end{array}$ & Режим плановых проверок \\
\hline 1 класс опасности & Чрезвычайно высокий & Более $1 \cdot 10^{-3}$ & Постоянно (не реже 1 раза в полгода) \\
\hline 2 класс опасности & Высокий & $10^{-4}<R \leq 1 \cdot 10^{-3}$ & Не реже 1 раза в 2 года, не чаще 1 раза в год \\
\hline 3 класс опасности & Значительный & $10^{-5}<R \leq 1 \cdot 10^{-4}$ & Не реже 1 раза в 3 года, не чаще 1 раза в год \\
\hline 4 класс опасности & Средний & $10^{-6}<R \leq 1 \cdot 10^{-5}$ & Не чаще 1 раза в 3 года \\
\hline 5 класс опасности & Умеренный & $10^{-7}<R \leq 1 \cdot 10^{-6}$ & Не чаще 1 раза в 5 лет \\
\hline 6 класс опасности & Низкий & $R<10^{-7}$ & Освобождаются от планового контроля \\
\hline
\end{tabular}

Для объектов, которым присвоена категория высокого и значительного риска, устанавливается максимальная и минимальная периодичность проведения плановых мероприятий государственного санитарно-эпидемиологического контроля (надзора).

Для объектов, которым присвоена категория среднего и умеренного риска, устанавливается только максимальная периодичность проведения плановых мероприятий государственного санитарно-эпидемиологического контроля (надзора).

В отношении объектов государственного контроля (надзора), которым присвоена низкая категория риска, плановые мероприятия государственного санитарно-эпидемиологического контроля (надзора) не проводятся.

Периодичность проведения плановых проверок субъектов надзора, относимых к 2-3-му классу опасности, может быть изменена следующим образом:

- если в результате проверок на объекте надзора за последние пять лет относительная частота нарушений санитарного законодательства меньше среднероссийского показателя, рассчитанного за тот же период, то частота проверок принимается минимальной;
- если в результате проверок на объекте надзора за последние пять лет относительная частота нарушений санитарного законодательства больше среднероссийского показателя, рассчитанного за тот же период, то период между плановыми проверками принимается с минимальной частотой.

Анализ результатов оценки потенциального риска причинения вреда здоровью объектами, осуществляющими разные виды деятельности в 4 регионах страны, позволил сделать ряд предварительных обобщений, которые могут представлять определенный интерес с точки зрения практического использования.

Так, к примеру, сравнение рассчитанных уровней потенциального риска показало, что среди лечебно-профилактических учреждений (за исключением деятельности детских санаториев и стоматологических кабинетов) наибольшие величины риска формируются в отношении многопрофильных больниц уровня Федерации или субъекта Федерации со стационарными отделениями (более 1000 коек) и с общим числом обслуживаемого контингента 80 тыс. человек в год и выше (с учетом посещений поликлиники) $\left(R>10^{-3}\right)$ (табл. 2). Такие ЛПУ могут быть отнесены к объектам, требующим постоянного надзора.

Таблица 2

Обобщенные результаты классификации лечебно-профилактических организаций (85.11-85.14, кроме деятельности детских санаториев)*

\begin{tabular}{|c|l|}
\hline $\begin{array}{c}\text { Класс потенциальной } \\
\text { опасности }\end{array}$ & \multicolumn{1}{|c|}{ Характеристика объекта надзора, осуществляющего данный вид деятельности } \\
\hline 1 -й & $\begin{array}{l}\text { Многопрофильная больница уровня Федерации или субъекта Федерации со стационарными отделе- } \\
\text { ниями (более } 1000 \text { коек) и с общим числом обслуживаемого контингента } 80 \text { тыс. человек в год и вы- } \\
\text { ше (с учетом посещений поликлиники) }\end{array}$ \\
\hline 2 -й & $\begin{array}{l}\text { Многопрофильная больница со стационарными отделениями (от } 300 \text { до 1000 коек) с общим числом } \\
\text { обслуживаемого контингента от } 10 \text { до } 80 \text { тыс. человек (с учетом посещений поликлиники) }\end{array}$ \\
\hline 3 -й & $\begin{array}{l}\text { ЛПУ без инфекционных и хирургических отделений (менее } 300 \text { коек) с общим числом обслуживае- } \\
\text { мого населения от 1000 до 10 тысяч человек }\end{array}$ \\
\hline $4-и ̆$ & $\begin{array}{l}\text { ЛПУ без инфекционных и хирургических отделений с общим числом обслуживаемого населения } \\
\text { менее от 100 до 1000 тысячи человек в год }\end{array}$ \\
\hline $5-и ̆$ & $\begin{array}{l}\text { Поликлиники и амбулатории без стационарных отделений с общим числом посещений менее } \\
100 \text { посещений в год }\end{array}$ \\
\hline 6 бй & \multicolumn{1}{|c}{ Нет } \\
\hline
\end{tabular}

П р и м е ч а н и е : * здесь и далее - по результатам анализа реестров Иркутской, Липецкой и Омской областей, Красноярского и Пермского краев. 
Многопрофильные больницы со стационарными отделениями (от 300 до 1000 коек) и общим числом обслуживаемого населения от 10 до 80 тыс. человек (с учетом посещений поликлиники) формируют популяционные риски, оцениваемые как высокие $\left(10^{-4}<R \leq 1 \cdot 10^{-3}\right)$. Лечебно-профилактические учреждения без инфекционных и хирургических отделений мощностью менее 300 коек и общим числом обслуживаемого населения от 1 до 10 тысяч человек в регионах имели показатели, которые позволяли квалифицировать их как объекты значитель- ного риска. Аналогичные объекты, но с меньшим числом обслуживаемых граждан (от 100 до 1000 человек), формировали класс объектов среднего риска и т.д.

Аналогичные обобщения позволили определить некоторые параметры промышленных предприятий, которые различаются по уровням риска и могут быть отнесены к разным классам (табл. 3); общеобразовательных детских учреждений (табл. 4), объектов торговли продуктами питания (табл. 5) и т.п.

Таблица 3

Предварительные итоги классификации промышленных предприятий по риску причинения вреда здоровью

\begin{tabular}{|c|c|}
\hline $\begin{array}{c}\text { Класс потенциальной } \\
\text { опасности }\end{array}$ & Характеристика объекта надзора, осуществляющего данный вид деятельности \\
\hline 1-й & $\begin{array}{l}\text { Промышленные предприятия, относимые к 1-му классу по санитарной классификации, расположен- } \\
\text { ные на территориях с плотностью населения свыше } 200 \text { чел./км², имеющие собственные выпуски } \\
\text { сточных вод и/или места по складированию отходов. } \\
\text { Имеются рабочие места с вредными и опасными условиями труда }\end{array}$ \\
\hline 2-й & $\begin{array}{l}\text { Промышленные предприятия, относимые к 1-му классу по санитарной классификации, расположен- } \\
\text { ные на территориях с плотностью населения менее } 200 \text { чел./км², имеющие собственные выпуски сточ- } \\
\text { ных вод и места по складированию отходов. } \\
\text { Промышленные предприятия, относимые к } 1 \text {-му классу по санитарной классификации, расположен- } \\
\text { ные на территориях с плотностью населения более } 200 \text { чел./км², не имеющие собственных выпусков } \\
\text { сточных вод и мест по складированию отходов. } \\
\text { Промышленные предприятия } 2,3 \text {-го классов по санитарной классификации, расположенные на терри- } \\
\text { ториях с плотностью более } 200 \text { чел./км², имеющие собственные выпуски сточных вод и места по скла- } \\
\text { дированию отходов. } \\
\text { Имеются рабочие места с вредными и опасными условиями труда }\end{array}$ \\
\hline 3-й & \begin{tabular}{|l} 
Промышленные предприятия 2, 3-го классов по санитарной классификации, не имеющие собственных вы- \\
пусков сточных вод и мест складирования отходов. Имеются рабочие места с вредными условиями труда
\end{tabular} \\
\hline 4-й & $\begin{array}{l}\text { Промышленные предприятия 4-го класса по санитарной классификации, не имеющие собственных } \\
\text { выпусков сточных вод и мест складирования отходов. }\end{array}$ \\
\hline 5-й & Промышленные предприятия 5-го класса (санзона не более 50 м) \\
\hline 6-й & $\begin{array}{l}\text { Производственные объекты, расположенные вне населенных пунктов, не имеющие рабочих мест } \\
\text { с вредными условиями труда работников }\end{array}$ \\
\hline
\end{tabular}

Предварительные результаты классификации общеобразовательных учреждений по риску причинения вреда здоровью

\begin{tabular}{|c|l|}
\hline $\begin{array}{c}\text { Класс потенциальной } \\
\text { опасности }\end{array}$ & \multicolumn{1}{|c|}{ Характеристика объекта надзора, осуществляюеего данный вид деятельности } \\
\hline 1 -й & $\begin{array}{l}\text { Нбщеобразовательные учреждения с численностью учащихся более 1500 человек. Общеобразова- } \\
\text { тельные учреждения с численностью учащихся более 1000 человек на территориях с нарушением } \\
\text { гигиенических требований к качеству питьевых вод и атмосферного воздуха }\end{array}$ \\
\hline 2 -й & Общеобразовательные учреждения с численностью учащихся 500-1500 человек \\
\hline 3-й & $\begin{array}{l}\text { Общеобразовательные учреждения с численностью учащихся от 50 до 500 человек. } \\
\text { Общеобразовательные учреждения с численностью } \\
\text { менее 50 человек, имеющие собственные котельные и источники питьевого водоснабжения }\end{array}$ \\
\hline 4-й & $\begin{array}{l}\text { Общеобразовательные учреждения с численностью } \\
\text { учащихся менее 50 человек }\end{array}$ \\
\hline 5-й & \multicolumn{2}{|c}{ Нет } \\
\hline 6-й &
\end{tabular}


Предварительные результаты классификации объектов торговли пищевыми продуктами, включая напитки и табачные изделия, по риску причинения вреда здоровью

\begin{tabular}{|c|l|}
\hline Класс & \multicolumn{1}{|c|}{ Характеристика объекта надзора, осуществляющего данный вид деятельности } \\
\hline 1 -й & \multicolumn{1}{|c|}{ Нет } \\
\hline 2 -й & $\begin{array}{l}\text { Торговля пищевыми продуктами, включая напитки, и табачными изделиями с числом обслуживаемо- } \\
\text { го населения порядка 14 тыс. в год и более. Наличие цехов по приготовлению полуфабрикатов }\end{array}$ \\
\hline 3 -й & $\begin{array}{l}\text { Торговля пищевыми продуктами, включая напитки, и табачными изделиями с числом обслуживаемо- } \\
\text { го населения порядка от 1 до 14 тыс. человек. Наличие цехов по приготовлению полуфабрикатов }\end{array}$ \\
\hline $4-и ̆ ~$ & $\begin{array}{l}\text { Торговля пищевыми продуктами, включая напитки, и табачными изделиями с числом обслуживаемо- } \\
\text { го населения порядка от 500 до 1000 человек }\end{array}$ \\
\hline 5 -й & $\begin{array}{l}\text { Торговля пищевыми продуктами, включая напитки, и табачными изделиями с числом обслуживаемо- } \\
\text { го населения порядка от 100 до 500 человек в год }\end{array}$ \\
\hline $6-и ̆ ~$ & $\begin{array}{l}\text { Торговля пищевыми продуктами, включая напитки, и табачными изделиями с числом обслуживаемо- } \\
\text { го населения порядка менее 100 человек в год }\end{array}$ \\
\hline
\end{tabular}

Следует отметить, что приведенные результаты получены при анализе оценок, выполненных на основании ограниченного круга данных (проанализировано порядка 6 тысяч ЮЛ и ИП и 11 тысяч объектов надзора, им принадлежащих). Апробация предложных подходов на примере полного федерального реестра, вероятно, позволит внести коррективы в классификационные признаки объектов разных классов по видам деятельности.

Вместе с тем предложенные методические подходы и полученные результаты классификации позволили уже в 2015 г. управлениям Роспотребнадзора в субъектах Федерации выполнить планирование контрольно-надзорных мероприятий с учетом риска причинения вреда здоровью [7].

В целом по стране общее число плановых проверок сократилось примерно на $20 \%$. Из-под планового надзоры выведены объекты низкого риска, которые в предшествующие три года не совершали существенных нарушений обязательных требований. Сокращение плановых проверок в наибольшей степени коснулось объектов торговли пищевыми продуктами, транспорта, производства пищевых продуктов, коммунального и бытового обслуживания. При этом объекты чрезвычайно высокого, высокого, значительного и среднего риска независимо от осуществляемого вида деятельности включены в планы проверок практически всех регионов страны.

Риск-ориентированная модель деятельности органов Роспотребнадзора находится в стадии становления. К важнейшим задачам ее развития и совершенствования относятся:

- закрепление процедуры определения класса объекта по риску причинения вреда здо- ровью населения по результатам ее апробации во всех регионах страны;

- выделение на основе результатов контрольно-надзорных мероприятий тех рисков для здоровья населения страны, которые требуется уменьшить и предотвратить с целью достижения санитарно-эпидемиологического благополучия;

- создание системы учета случаев причинения вреда жизни и здоровью при нарушении санитарного законодательства;

- формирование исчерпывающего, перечня обязательных, единообразно трактуемых санитарно-эпидемиологических требований к осуществлению видов деятельности, зданиям, сооружениям, установкам и т.п.;

- научное обоснование и разработка административного регламента по объемам, содержанию и лабораторному сопровождению плановых проверок объектов, относящихся к разным классам по риску причинения вреда здоровью населения;

- расширение сферы риск-ориентированного надзора на системы технического регулирования и защиты прав потребителей;

- совершенствование порядка и методов оценки результативности и эффективности рискориентированной надзорной деятельности;

- повышение квалификации специалистов надзорных подразделений в части оценки риска и риск-менеджемента;

- создание эффективной системы рисккоммуникаций между органами санитарноэпидемиологического надзора, хозяйствующими субъектами, общественными организациями и объединениями и гражданским обществом. 


\section{Список литературы}

1. Контрольно-надзорная деятельность в Российской Федерации: аналитический доклад - 2014. - М.: МАКС Пресс, 2015. - 120 c.

2. Мельников Р. Концептуальные подходы к формированию систем риск-ориентированного регулирования // Методы управления. - 2011 № 5. - С. 26-29.

3. О порядке определении численности населения под воздействием неблагоприятных факторов среды обитания при проведении СГМ: методические рекомендации // Управление Роспотребнадзора по Республике Башкортостан, 2012. - 14 с.

4. Приказ руководителя Роспотребназора Роспотребнадзора № 927 от 21.09.2015 г. «О Федеральном реестре юридических лиц и индивидуальных предпринимателей». - URL: http://www.rospotrebnadzor.ru/privat/ID=2622 (дата обращения: 10.11.2015).

5. Приказ руководителя Федеральной службы в сфере защиты прав потребителей и благополучия человека № 1302 от 26.12.2014 г. «О внедрении Методических рекомендаций в «пилотных» территориальных органах Роспотребнадзора». - URL: http://www.rospotrebnadzor.ru/privat/ID=2847 (дата обращения: 10.11.2015).

6. Приказ руководителя Федеральной службы в сфере защиты прав потребителей и благополучия человека № 1008 от 30.09.2015 г. «О внедрении методических рекомендаций «Классификация хозяйствующих субъектов и видов деятельности по потенциальному риску причинения вреда здоровью человека для организации плановых контрольно-надзорных мероприятий». - URL: http:/www.rospotrebnadzor.ru/privat/ID=4374 (дата обращения: 12.11.2015).

7. Приказ руководителя Федеральной службы в сфере защиты прав потребителей и благополучия человека № 464 от 25.05.2015 г. «О внедрении риск-ориентированного подхода в контрольно-надзорную деятельность территориальных органов Роспотребнадзора». - URL: http://www.rospotrebnadzor.ru/privat/ID=3126 (дата обращения: 15.11.2015).

8. Ферапонтов А.В. Принципы организации риск-ориентированного надзора за опасными производственными объектами // Безопасность труда в промышленности. - 2010. - № 6. - С. 4-7.

9. Черток В.Б. Принципы инновационного развития систем контроля и надзора за обеспечением авиационной безопасности на разных уровнях с учетом риск-ориентированных моделей // Качество и жизнь. 2015. - № 3 (7). - C. 43-46.

10. Bender W.J., Ayyub B.M. Risk-based cost control for construction // AACE International Transactions. 2000. - C. 11 .

11. Powell C., Laxton's Guide to Risk Analysis and Management, Laxton's Publishers, Jordan Hill. - Oxford, 1996. $-116 \mathrm{p}$.

\section{References}

1. Kontrol'no-nadzornaja dejatel'nost' v Rossijskoj Federacii: Analiticheskij doklad [Supervisory activities in the Russian Federation: Analytical report - 2014]. M.: MAKS Press, 2015, 120 p. (in Russian).

2. Mel'nikov R.M. Konceptual'nye podhody $\mathrm{k}$ formirovaniju sistem risk-orientirovannogo regulirovanija [Conceptual approaches to the formation of systems of risk-based regulation]. Metody upravlenija, 2011, no. 5, pp. 26-29. (in Russian).

3. O porjadke opredelenii chislennosti naselenija pod vozdejstviem neblagoprijatnyh faktorov sredy obitanija pri provedenii SGM. Metodicheskie rekomendacii [On the procedure of the population determination under the impact of adverse environmental factors during the sanitary and hygienic measures. Guidelines]. Upravlenie Rospotrebnadzora po Respublike Bashkortostan, Ufa, 2012, 14 p. (in Russian).

4. O Federal'nom reestre juridicheskih lic i individual'nyh predprinimatelej: Prikaz rukovoditelja Rospotrebnazora ot 21.09.2015 № 927 [On the Federal Register of legal entities and individual entrepreneurs: Order of the head of Rospotrebnadzor dated 21.09.2015 №927]. Available at: http://www.rospotrebnadzor.ru/privat/ID=2622.

5. O vnedrenii Metodicheskih rekomendacij v «pilotnyh» territorial'nyh organah Rospotrebnadzora: Prikaz rukovoditelja Federal'noj sluzhby v sfere zashhity prav potrebitelej i blagopoluchija cheloveka ot 26.12.2014 № 1302 [On the implementation of the Methodological recommendations on the "pilot" territorial bodies of Rospotrebnadzor: Order of the head of the Federal Service in Consumer Rights Protection and Human Welfare dated 26.12.2014 № 1302]. Available at: http://www.rospotrebnadzor.ru/privat/ID=2847.

6. O vnedrenii Metodicheskih rekomendacij «Klassifikacija hozjajstvujushhih sub\#ektov i vidov dejatel'nosti po potencial'nomu risku prichinenija vreda zdorov'ju cheloveka dlja organizacii planovyh kontrol'no-nadzornyh meroprijatij: Prikaz rukovoditelja Federal'noj sluzhby v sfere zashhity prav potrebitelej i blagopoluchija cheloveka ot 30.09.2015 № 1008 [On the implementation of the Methodological Recommendations of "Classification of economic entities and activities on the potential risk of harm to human health for the organization of the planned supervisory activities: Order of the head of the Federal Service in Consumer Rights Protection and Human Welfare dated 30.09.2015 № 1008]. Available at: http://www.rospotrebnadzor.ru/privat/ID=4374.

7. O vnedrenii risk-orientirovannogo podhoda v kontrol'no-nadzornuju dejatel'nost' territorial'nyh organov Rospotrebnadzora: Prikaz rukovoditelja Federal'noj sluzhby v sfere zashhity prav potrebitelej i blagopoluchija cheloveka 
ot 25.05.2015 № 464 [On the implementation of a risk-based approach to compliance and enforcement activities of the territorial bodies of Rospotrebnadzor: Order of the head of the Federal Service in Consumer Rights Protection and Human Welfare dated 25.05.2015 № 464]. Available at: http://www.rospotrebnadzor.ru/privat/ID=3126.

8. Ferapontov A.V. Principy organizacii risk-orientirovannogo nadzora za opasnymi proizvodstvennymi ob\#ektami [The organization principles of risk-based supervision of hazardous industrial objects]. Bezopasnost ${ }^{\prime}$ truda v promyshlennosti, 2010, no. 6, pp. 4-7. (in Russian).

9. Chertok V.B. Principy innovacionnogo razvitija sistem kontrolja i nadzora za obespecheniem aviacionnoj bezopasnosti na raznyh urovnjah s uchetom risk-orientirovannyh modelej [The principles of innovative development of systems of control and supervision of aviation security at different levels, taking into account the risk-based models]. Kachestvo i zhizn', 2015, no. 3 (7), pp. 43-46. (in Russian).

10. W.J. Bender, B.M. Ayyub: Risk-Based Cost Control for Construction. AACE International Transactions, Morgantown 2001, s. CSC.01.1.

11. Powell C. Laxton's Guide to Risk Analysis and Management, Laxton's Publishers, Jordan Hill, Oxford, $1996,116 \mathrm{p}$.

\title{
ON THE DEVELOPMENT OF THE SYSTEM OF RISK-BASED SUPERVISION IN THE FIELD OF SANITARY AND EPIDEMIOLOGICAL WELFARE OF THE POPULATION AND CONSUMER PROTECTION
}

\author{
A.Y. Popova ${ }^{1}$, N.V. Zaitseva ${ }^{2}$, I.V. May $^{2}$, D.A. Kiryanov ${ }^{2}$ \\ ${ }^{1}$ Federal Service on Customers' Rights Protection and Human Well-Being Surveillance, \\ Russian Federation, Moscow, 18 Vadkovsky Pereulok St., building 5 and 7, 127994 \\ ${ }^{2}$ FBSI "Federal Scientific Center for Medical and Preventive Health Risk Management Technologies", \\ Russian Federation, Perm, 82 Monastyrskaya St., 614045
}

In order to fulfill the legal requirements for the transition to the new risk-based model of the state control (supervision) in the Federal Service for Consumer Rights Protection and Human Welfare, the methodical approaches to the classification of economic entities and activities of potential risk of injury have been developed. The risk assessment takes into account the frequency of violations of sanitary legislation, the severity of the consequences of these violations for the health and extent of negative effects, which is estimated in terms of population under the influence of the economic entity. Algorithms and methods for calculating the exposed population: workers, consumers, including consumer food products, non-food products and services; residents of settlements under the negative impact of air pollution, water and soil, have been developed. Regional and federal registries of objects for sanitary and epidemiological supervision are formed. Testing of the risk-based approaches in the regions allowed excluding the low risk harm objects when forming the audit plans for 2016, due to what the number of planned inspections all over country was reduces by more than $20 \%$. The basic directions of further improvement of the risk-based model of sanitary and epidemiological surveillance: its extension to the system of technical regulation and consumer protection; scientific substantiation of its volume, content and laboratory support of the scheduled inspections of objects belonging to different classes of health risk; improving procedures and methods for evaluating the effectiveness and efficiency of risk-based supervisory activities; creation of an effective system of risk communication between the sanitary and epidemiological surveillance, economic entities, public organizations and associations and civil society.

Key words: risk-based sanitary and epidemiological surveillance, the population under exposure.

(C) Popova A.Y., Zaitseva N.V., May I.V., Kiryanov D.A., 2015

Popova Anna Yurievna - Doctor of Medicine, director (e-mail: depart@gsen.ru; tel.: +7 (499) 458-95-63).

Zaitseva Nina Vladimirovna - member of the academy of RAMS, Doctor of Medicine, professor, director (e-mail: znv@fcrisk.ru; tel.: +7 (342) 237-25-34).

Mai Irina Vladislavovna - Doctor of Biological Sciences, professor, deputy director for scientific work (e-mail: may@fcrisk.ru; tel.: +7 (342) 236-32-64).

Kiryanov Dmitry Alexandrovich - Ph.D. in Technical Sciences, head of the department of mathematical modeling of systems and processes (e-mail: kda@fcrisk.ru; tel.: +7 (342) 237-18-04). 